\title{
Analysis Of Payment Accounting System At Pt Aplus Pasific
}

\author{
Ertie Nur Hartiwati \\ Faculty of Computer Science, Gunadarma University \\ *Corresponding Author: \\ Email:Ertie@staff.gunadarma.ac.id
}

\begin{abstract}
.
To find out whether a company is a company that has a good and correct system, a control system is needed that can make the company more thorough and have more specific and good payroll data. The internal control system is one of the accounting information systems. implemented by the company in achieving its corporate goals. In realizing a good and appropriate company system, an analysis and evaluation is needed. Where it is expected to be able to prevent fraud that can occur within a company.The analytical method used is Flowchart (Flow Chart), an analytical technique used to describe several aspects of an information system in a clear, concise, and logical manner. Flowcharts use standard symbols to describe through pictures the transaction processing procedures used by the company and the flow of data through the system. The benefits of this system to help clarify complex processes in the decision-making process.The conclusions obtained from the Payroll Accounting Information System Analysis, the company seeks to implement the accounting function properly. However, the company has not implemented a payroll information system that is more complex so that it can cause errors in the payroll system within the company.
\end{abstract}

Keywords: Accounting Information System, Payroll, Unified Modeling Language, PT. World Innovative

Communication

\section{INTRODUCTION}

Along with the development of the era, many companies employ employees to help manage a company called employees, there are permanent and temporary employees, the researchers here will explain about how the payroll is carried out by the PT Aplus Pacific company. The existence of an adequate payroll accounting system makes corporate accountants able to provide financial information for every level of management, owners or shareholders, creditors, and users of financial statements that are used as the basis for making economic decisions. The payroll accounting system can be used by management to plan and control how to make payroll in a company. Human resources are one of the resources that can be utilized by a company for the continuity of a business. Human resources play an important role in determining whether the company can achieve its business goals properly. Companies need employees, as well as companies need employees for company operations. Employees need work to earn a salary that can be used for the survival of the employee. According to Manullang (2001: 57) salary is a gift to employees with payment in the form of money as remuneration for a job that has been carried out as a gift of enthusiasm for implementation and activities in the future. One system that can be used by company management is the payroll accounting system.

This payroll accounting system was created to overcome errors and irregularities in the calculation and payment of salaries. The salary accounting system was also created by the company to provide a clear picture of employee salaries so that it is easy to understand and easy to use. To find out whether a company is a company that has a good and correct system, a control system is needed that can make the company more thorough and have more specific and good payroll data. The internal control system is one of the accounting information systems implemented by the company in achieving its goals his company. In realizing a good and appropriate 
company system, an analysis and evaluation is needed. Where it is expectedbe toable to prevent fraud that can occur within a company. PT Aplus pacific is an innovative solution to provide wall materials - participation, ceiling, floor and other building material products. PT Aplus Pacific, is a rapidly growing company in the field of building materials. This development at the PT Aplus Pacific company requires good supervision to minimize fraudulent actions that can occur. And can improve the performance of company employees.

\section{LITERATURE REVIEW}

\subsubsection{System}

There are several definitions of the system according to experts, including:

According to Mulyadi (2001: 2) the system is as follows, "A system is basically a group of elements that are closely related to one another, which function together- together to achieve certain goals. According to Widjayanto (2001: 2; Fudy 2012) "The system is something that has interacting parts to achieve certain goals through three stages, namely: input, process and output". According to James A. Hall (2001: 5; Fudy 2012) "A system is a group of two or more inter-related components or subsystems that unite to achieve the same goal (common purpose)."

\subsubsection{Accounting System}

Warren, Reeve, and Fess (2005: 226; fudy 2012) argues that: "The accounting system is a method and procedure for collecting, classifying, summarizing, and reporting on operating and financial information of a company." According to Mulyadi (2001: 3) "the accounting system is the organization of forms, records, and reports that are coordinated in such a way as to provide financial information needed by management to facilitate the management of company data".

\subsubsection{Accounting Information Systems}

According to Bodnar and Hopwood (2004: 1; Fudy 2012): "Accounting information systems (AIS) are a collection of resources, such as humans and equipment that are arranged to convert financial data and other data into information". Romney and Steinbart (2004: 473) state that "Accounting information systems (AIS) are human and capital resources in organizations that are responsible for (1) preparation of financial information and (2) information obtained from collecting and processing various company transactions".

\subsubsection{Objectives of the Accounting System}

Quoted from the journal Mohammad Tufiq Hidayat: 2013. The general objectives of developing an accounting system are as follows:

1. To provide information for the management of new business activities. This goal occurs when a new company is established / a company creates a new business that is different from the business that has been running so far. A newly established company usually requires the development of a more complete accounting system than a company that opens a new business.

2. To improve the information generated by the existing system. This improvement was carried out both in terms of quality, provision of presentation and structure of information contained in the report. This is probably due to the development of the company's business, so it is also necessary to improve the information generated by the existing system.

3. To improve accounting control and internal checking. Namely to improve the level of reliability (reliability) accounting information and to provide a complete record of the liability and protection of company assets. If theobtaining financial information are calculated to be greater than the benefits obtained, then the costs ofexisting accounting system needs to be redesigned to reduce the costs incurred. (Mulyadi, 2001: 1920).

\subsubsection{Salary}

Salary or in English known as salary is a form of periodic payment from a company to an employee which may be based on an employment contract. From the point of view of running a business, salary can be 
seen as the cost needed to run a company.

The definition of salary from several experts include:

- Mulyadi (2001: 373) provides a definition of salary and wages are as follows: salary is payment for the delivery of services performed by employees who have managerial positions, generally salaries are given on a monthly basis.

- According to PP. 8 of 1981 "Salary and Wages are an income as a reward from employers to workers for a job or service that has been or will be performed, declared or valued in the form of money determined according to an agreement or statutory regulation and paid on the basis of a work agreements between employers (employers) and workers including allowances for both the workers themselves and their families.

- According to T. Hani Handoko (2001:245), salary is very important for employees as individuals because salary is a measure of the value of their work among the employees themselves, their families and society.

The amount of salary tends to be fixed and can go up or down according to company policy. In general, the amount of the salary will be fixed for several periods. The basis for giving salary itself can be from company policies and government policies regarding payroll. Company policy can be obtained by comparing the salary levels of other companies that are similar to the company in one area. Type of work, length of work, and rank are some of the factors that determine the determination of an employee's salary. The pay period is also in a fixed period or period of time. Public and private employees will generally get a salary within a period of once a month (beginning or end of the month). There are also those who may get a salary every two weeks, every two months, or other periods according to the work agreement between the company and the worker.

\section{METHODS}

Data Collection Techniques

To obtain the data needed in scientific writing, the authors use the following methods:

\section{Observation}

This method is carried out by field research (field research) and data taken from PT Aplus Pacific.

\section{Interview}

This method is carried out by the author through interviews with related parties to obtain the data needed in this scientific preparation.

\section{Analysis Tools Used}

The method used by the author is descriptive analysis, namely the author analyzes the problem by describing or describing the reality that exists in the company and compares it with standard theory so that a conclusion is obtained. In this case the author uses the document flowchart method (flowchart).

\section{RESULTS AND DISCUSSION}

\subsubsection{Documents of the payroll system used at PT Aplus Pacific}

\subsubsection{Documents used}

1. Salary Procedures for Human Resources

1. Managing Employee Attendance Lists to calculate salaries to be given

2. Making Advances to Employees.

3. Submit a list of employee salaries and an advance letter to the employee to the General Manager.

\section{Payroll Procedures for General Manager Phase I}

1. Receive Employee Attendance List, Advance Letter to Employees.

2. Calculating the Total Salary of Employees.

3. Sending a Letter of Total Employee Salary to the Finance section.

\section{Payroll procedures for finance}

1. Receive a total salary letter from the General Manager. 
2. Make a salary approval letter.

3. Prepare warrants for issuing cash and checks.

4. Sending Warrants to Issue Money, Checks, Letters of Approval of Salaries and Letters of Total

5. Employee Salaries to the General Manager.

4. Payroll Procedures for General Manager Section II

1. Receiving Orders to Disburse Money, Checks and Letters of Approval for Payment of Salaries and Letters of Total Employee Salaries from the Finance Department.

2. Signing the Warrant to Issue Money.

3. Sending Total Salary of Employees, Letter of Approval for Payment of Salaries, Checks and Orders to Disburse Money to the bank, so that the bank directly delivers it to employees on the specified date

\section{Flowchart of the Human Resources section}

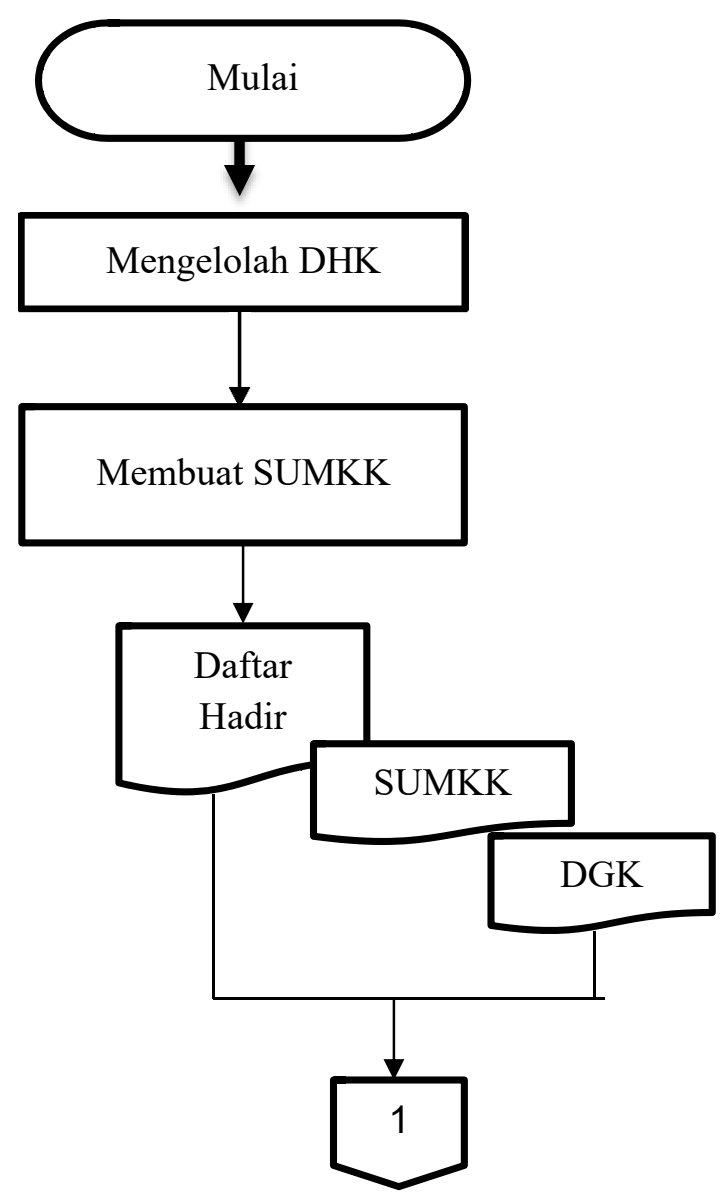

DHK :Daftar Hadir Karyawan

Fig 4.

SUMKK : Surat Uang Muka Kepada Karyawan

DGK : Daftar Gaji Karyawan

TGK : Total Gaji Karyawan

SPMU : Surat Perintah Mnegeluarkan Uang

SPPG : Surat Persetujuan Pembayaran Gaji

STGK : Surat Total Gaji Karyawan 
General Manager Section Flowchart

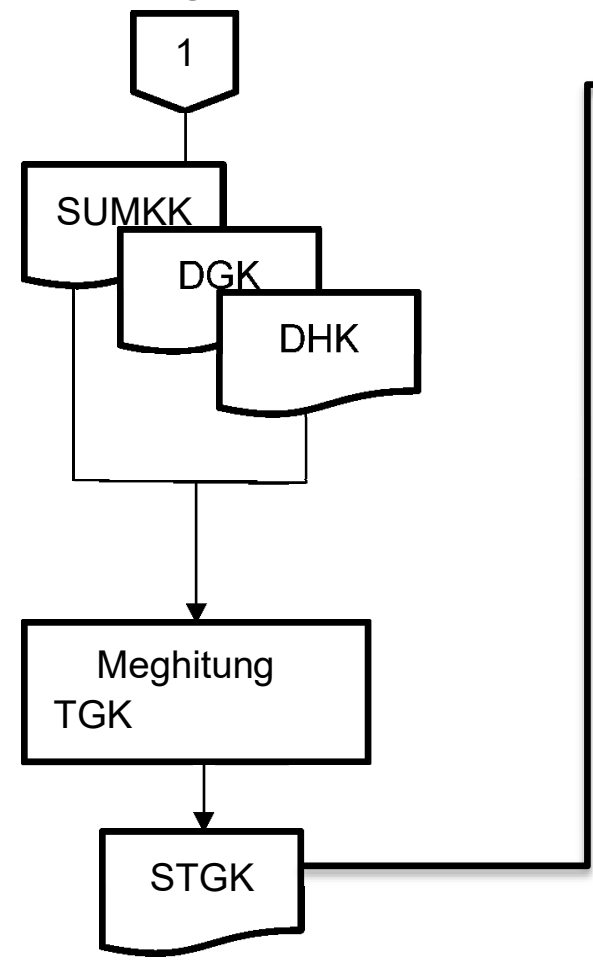

Finance Section Flowchart

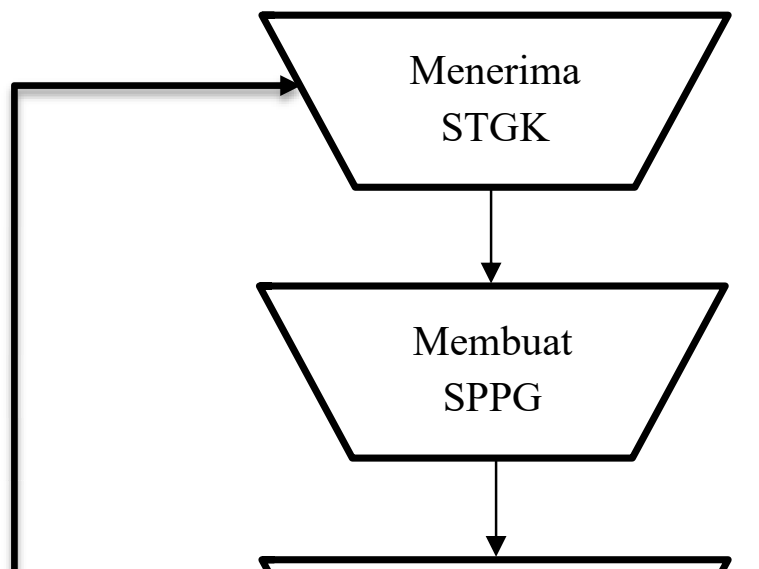

Mempersiapka

n SPMU dan

Cek

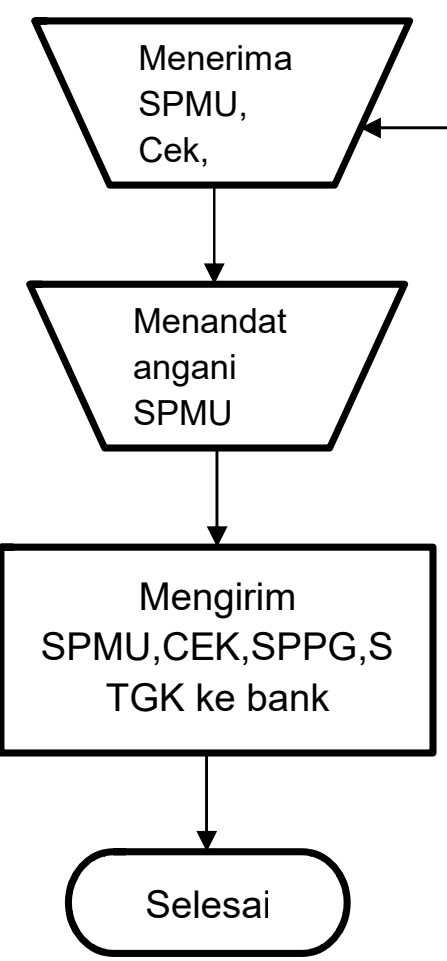

Fig 4.2 


\subsubsection{Orgaorgnizational Units related to the internal control system with the company}

\section{Human Resources}

- Manage Employee Attendance List to calculate salary which will be given. Making Advances to Employees. $\Rightarrow$ It has become a liability and are in accordance with the internal control system as part of the human resources to manage the attendance list and make a report in advance to the department concerned.

- Submit employee salary lists and advances to employees to the General Manager.

$\Rightarrow$ It is not reasonable and violated the rules of the internal control system in general that if the human resources submitted a list of salaries to finance part / cashier and do not forget the accounting department also plays a role in the recording as an expense in the company.

\section{General Manager Phase I}

- Receive Employee Attendance List, Advance Letter to Employees. Calculate Total Employee Salary. Send Employee Total Salary Letter to Finance.

$\Rightarrow$ There are some parts that violates the rules of the internal control system such as calculating the total salary of the employee, that the task of calculating the salaries of employees contained in the finance department, because if the task is on hold by the general manager then this can be said to be doubling the work (double job).

\section{The finance department In}

Principle, he (finance) holds the money, he has the authorization to issue and receive money, be it cash, as well as money in banks, deposits, and other financial investments.

- Make a salary approval letter. Prepare warrants for issuing cash and checks. Sending Warrants to Issue Money, Checks, Salary Approval Letters and Total Employee Salary Letters to the General Manager.

The company is quite good in the finance department because the finance department received a total salary letter.

\section{Section II General Manager}

Receives Warrants to Disburse Money, Checks and

Letters of Approval for Payment of Salaries and Letters of Total Employee Salaries from the Finance section.

- Signing the Warrant to Disburse Money.

$\Rightarrow$ Section above is in conformity with the internal pengendalia system, because it is supposed to monitor the general manager, manandatangi and directing staff and employees to contribute in their respective roles.

- Sending Total Salary of Employees, Letter of Approval for Payment of Salaries, Checks and Orders to Disburse Money to the bank, so that the bank directly delivers it to employees on the specified date.

This section does not match the internal control system because according to SPI, the work is the authority of the finance department.

\subsubsection{Analysis of the functions used at PT Aplus Pacific}

\section{Accounting function}

PT Aplus Pacific has not implemented the accounting function, this is reflected in information and interviews with related staff. The company's accounting function is an important function in managing the company.

\section{Financial}

Function The financial function at PT Aplus Pacific has been running well, this is reflected in the functions that are in accordance with procedures and the duplication of functions from what should be.

\section{Payroll Maker Function}

In the payroll register function, this is reflected in the elements that should be submitted by the payroll register function to the accounting department, but because the accounting function does not exist, the payroll register function submits directly to the General Manager so that it is not appropriate with functions according to procedures. 


\section{Timekeeping function}

PT Aplus Pasific'sin terms of timekeeping is quite good, this is reflected in that every staff related functionhas used a computer to perform attendance and check attendance.

\section{Staffing}

Function The existing staffing function at PT Aplus Pacific is good, this can be seen from the separation of existing functions and responsibilities.

\subsubsection{Analysis of Internal Payroll System Control}

From the data obtained by the author, it can be seen that the control environment is not well reflected in the related functions of the organizational structure that clearly regulates the duties and authorities of each control system function such as the accounting department which is not responsible for payroll recording. The risk that may arise due to the loss of the accounting function, for example fraud in payroll, is quite large. This may fall outside the acceptable range of risk tolerance. The resulting information is not of high quality to communicate the payroll system. The supervision carried out by the company has not been effective due to the absence of error correction even though, supervision is an important part to improve performance and correct existing errors.

\section{CONCLUSION}

Based on the analysis of the research results and the discussion that has been described previously, the authors conclude that:

- PT Aplus Pacific's existing payroll system is good, although there are some that are not in accordance with the Internal Control System.

- there is no regular separation of functions and responsibilities between units such as the doubling of work within the company contained in the General Manager.

\section{REFERENCES}

[1] Achmad S. Ruky. 2016. Payroll and Wage Management for Company Employees. First Edition, Jakarta: PT. Main Library Gramedia.

[2] Aryanto Mahatmyo. 2014. Accounting Information System An Introduction. First Edition. Yogyakarta: Depublish.

[3] Dewi Fitriasari, and Deny Arnos Kwary (Translator). 2007. Information Technology Audit and Assurance. Second edition, Jakarta: Salemba Empat.

[4] Fudy Anisa. 2012. Analysis of Payroll Accounting Information Systems at PT Pertani (Persero). Essay. Gunadarma University.

[5] Jones, Frederick L., and Dasharatha V. Rama. 2008. Accounting Information System. Eighteenth Edition, Jakarta: Salemba Empat.

[6] Lamhot Sitorus. 2015. Algorithms and Programming. First Edition. Yogyakarta: ANDI.

[7] Manullang M. 2001. Human Resource Management. (1st edition), Yogyakarta : BPFE-Yogyakarta.

[8] Mulyadi.2001. System Accounting. Third Edition, Jakarta: Salemba Empat.

[9] Mohammad Taufiq, Hidayat Sri Mangesti, Rahayu Achmad Husaini. 2013. Analysis of the Implementation of the Payroll and Wage Accounting System in Supporting Internal Control. Journal of Business Administration. Brawijaya University Malang.

[10] Romey, Mashal B., and Paul John Stainbart. 2016. Accounting Information System. Thirteenth Edition. Jakarta: Four Salemba.

[11] Twilight Nilasari.2016. A Practical Guide to Developing a Payroll and Benefit System. Jakarta: Achieve Success.

[12] T. Hani Handoko, 2001, Personnel Management and Human Resources, twelfth printing, Yogyakarta: BPFE

[13] Warren, Reeve, Fess, 2005. Introduction to Accounting, Edition 21, Salemba Empat Publisher, Jakarta 